UDC 547.11:615.212.4

\title{
PREPARATION AND STUDY OF THE PROPERTIES OF THE COPOLYMER OF CYCLIC UNSATURATED BISMALEIMIDE WITH STYRENE
}

\author{
A.I.Alikhanova, R.Sh.Rasulzade \\ Institute of Polymer Materials, NAS of Azerbaijan \\ aygun81@mail.ru
}

Received 21.06.2021

Accepted 12.08.2021

\begin{abstract}
The paper is devoted to the study of regularities of radical copolymerization reactions of unsaturated cyclic N,N'-bisimides $\left(\mathrm{M}_{1}\right)$ with styrene $\left(\mathrm{M}_{2}\right)$, the study of dependence of copolymerization reaction rate, composition of obtained copolymers, composition and estimated molecular weight on the composition of the initial monomer mixture. With the increase of bismaleimide amount in the initial monomer mixture a decrease of copolymerization reaction yield and molecular weight of the obtained copolymers was observed. This fact can be explained by active participation of bismaleimide in chain transfer in radical copolymerization reaction. The composition of the obtained copolymers in all cases is rich in styrene links.
\end{abstract}

Keywords: unsaturated cyclic bisimides, styrene, copolymer, copolymerization constants, antimicrobial and fungicidal properties.

doi.org/10.32737/0005-2531-2021-4-25-29

\section{Introduction}

Polystyrene (PS) is of great importance as a modern construction material in combination with general-purpose styrofoam, impact-resistant polystyrene and ABC (acrylonitrile-butadienestyrene). Although polystyrene makes up $6 \%$ of the world's polymer materials in the form of plastic mass, it is widely used in many areas of household chemicals, construction and automotive industries [1,2].

One of the most widely used areas of PS is the production of packaging material for food products by thermoforming. It is important that the resulting polystyrene of this type is resistant to widespread microbes and microfungi $[3,4]$.

One of the most common methods for the formation of antibacterial properties of polymers is the inclusion of a monomer fragment with antibacterial properties into macrochains at the stage of their synthesis [5].

The aim of this work is to develop a technology for the synthesis of styrene copolymers with unsaturated cyclic N,N'-bisimide of maleic acid to obtain an antibacterial copolymer and to study its physico-mechanical and bactericidal properties [6].

\section{Experimental part}

N,N'-(4,4-diphenylmethane)bismaleinimide obtained by a known method by the interaction of (4,4-diphenylmethane)diamine with maleic anhydride [7].

Styrene $\left(\mathrm{C}_{6} \mathrm{H}_{5}-\mathrm{CH}=\mathrm{CH}_{2}\right)-$ used industrial (b.p. $-25.5^{0} \mathrm{C}, \rho-0.9060, n_{D}^{20}-1.5462$ ).

The copolymerization of N,N'-(4,4-diphenylmethane)bisimide of maleic acid $\left(\mathrm{M}_{1}\right)$ with styrene $\left(\mathrm{M}_{2}\right)$ was carried out in a glass ampoule in a solution of methyl ethyl ketone in the presence of $0.2 \%$ benzene peroxide (BP) at a temperature of $75^{\circ} \mathrm{C}$ for 4 hours. The total density of the resulting mixture of monomers was constant, $1.0 \mathrm{~mol} / \mathrm{l}$, and the ratio of monomers changes accordingly. The resulting copolymer was precipitated methanol from methyl ethyl ketone several times, and then dried in a vacuum $\left(30-40 \mathrm{~mm} \mathrm{Hg}\right.$ ) at a temperature of $40^{\circ} \mathrm{C}$ to a constant weight.

The obtained copolymer in the form of a white powder is highly soluble in methyl ethyl ketone and chlorinated organic solvents. The composition of copolymers is determined by the value of the unit of etherization.

The characteristic viscosity was determined by a Ubbelode viscometer [8]. The IR spectra of the samples were recorded on an Alpha-IR Fourier spectrometer (BRUKER, Germany), in the range of $600-4000 \mathrm{~cm}^{-1}$ [9].

\section{Results and discussion}

The copolymerization reaction was carried out as follows: 


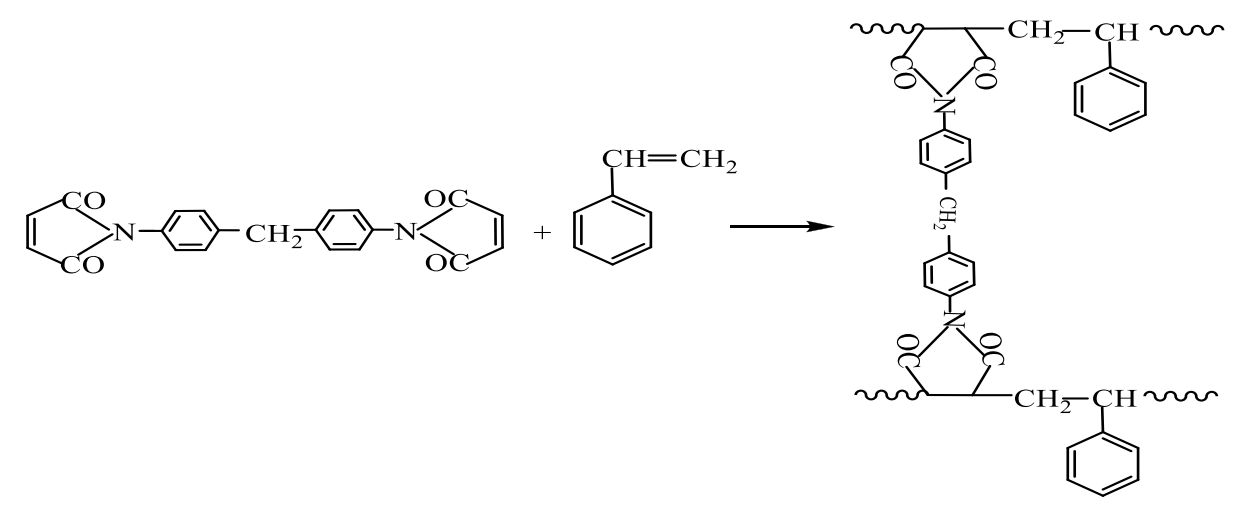

The parameters of copolymerization (relative activity of monomers $-r_{1}$ and $r_{2}$ ) were determined kinetically. There is also a dependence on composition, composition and properties. Constants of copolymerization were calculated according to the Mayo-Lewis equation.

The composition and structure of the copolymers were determined based on the IR spectra of the resulting styrene copolymer (Figure $1 a$ ) and styrene copolymer (Figure $1 b$ ). Comparison of the IR spectra (Figures $1 a$ and 1b) showed that in the spectra of the styrene copolymer, absorption bands were observed in the region of $1773 \mathrm{~cm}^{-1}$ and there were no absorption bands up to the $(\mathrm{C}-\mathrm{O})$ group, $(\mathrm{N}-\mathrm{C})$, while in the IR spectra of the resulting copolymer with bismaleinimide, absorption bands of the $(\mathrm{C}=\mathrm{O})$ bond were found at $1694 \mathrm{~cm}^{-1}$, for
(C-C) bonds in the region of $1707 \mathrm{~cm}^{-1}$, for (N-C) bonds in the region of $1326 \mathrm{~cm}^{-1}$.

The parameters of the copolymer microstructure were calculated based on the copolymerization constants (Table 1).

From Table 1, it can be seen that the composition of the copolymers is enriched in styrene units. With an increase in the number of bismaleinimide units in the copolymer of bismaleinimide with $\mathrm{St}$, the rate and degree of the polymerization reaction decreases. $\left(r_{1}=0.01\right.$ for a pair of bismaleinimide-St; $r_{2}=12.5$ ).

As can be seen from Table 2, with an increase in the relative amount of bismaleinimide in the monomer mixture, a sharp decrease in the yield of the copolymer, the characteristic viscosity and the average molecular weight of the copolymer is observed.

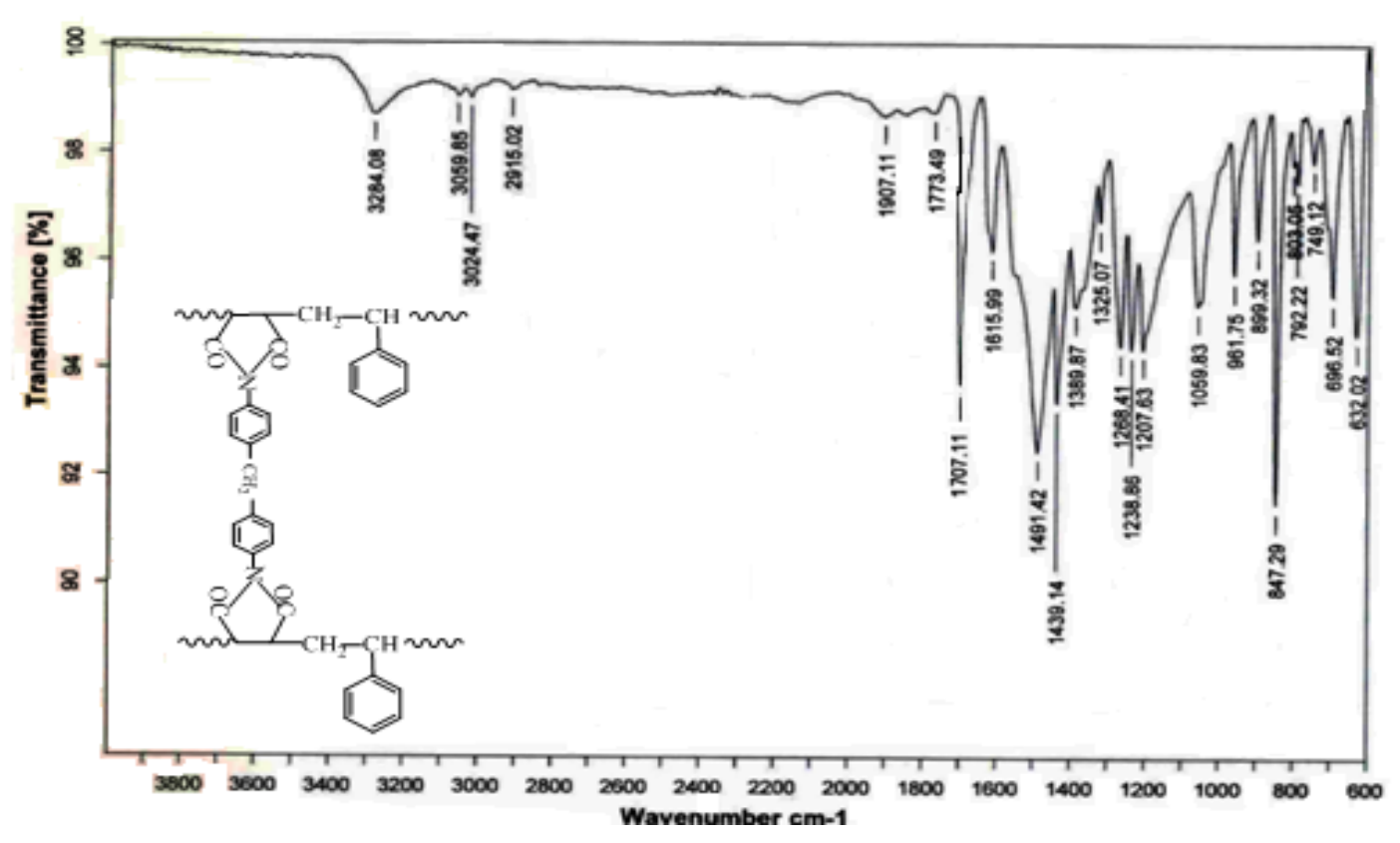

Fig. 1a. IR spectrum of N, N'- (4.4-diphenylmethane)bismaleinimide -Styrene copolymers. 


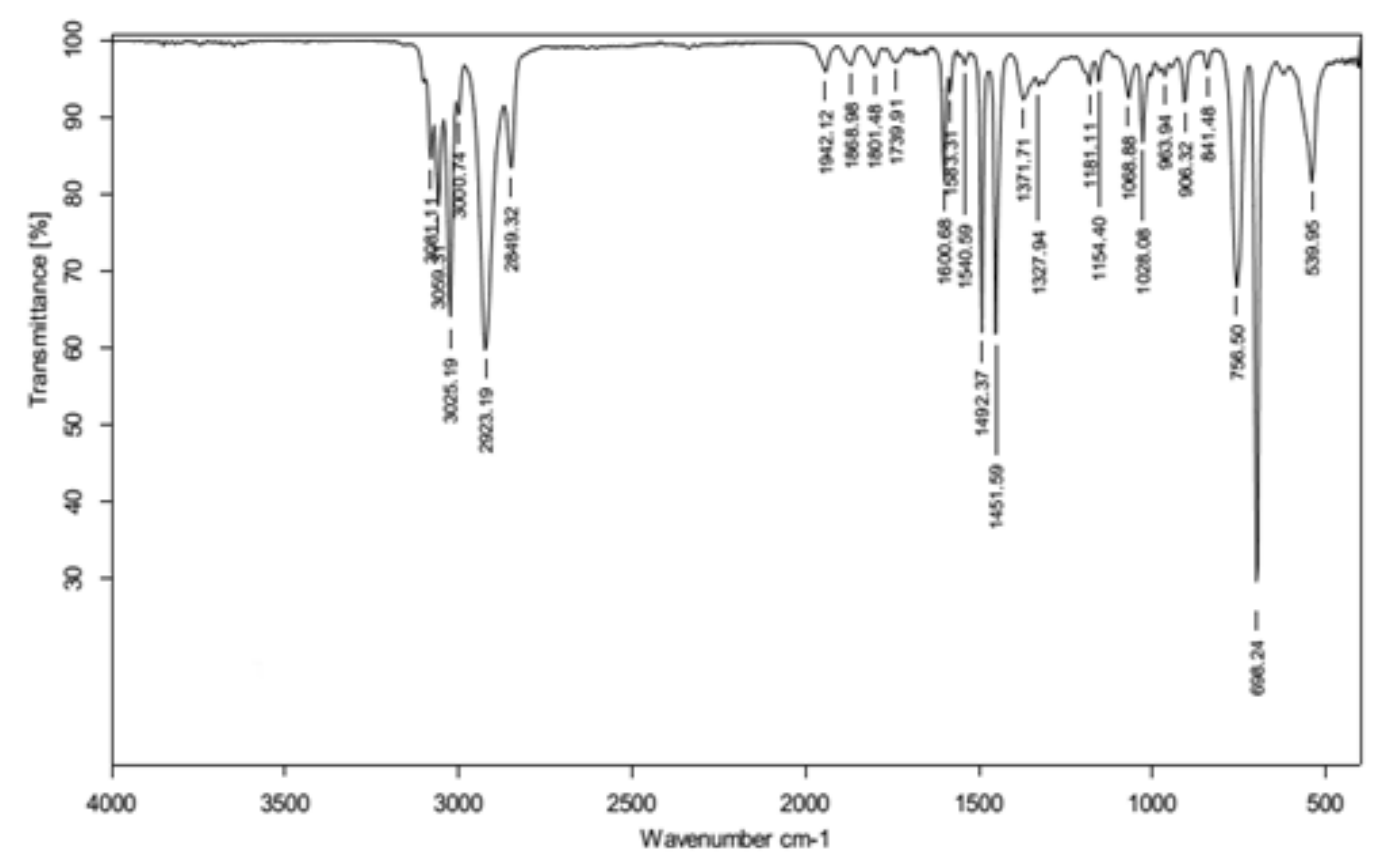

Fig. $1 b$. IR spectrum of polystyrene.

Table 1. Indicators for calculating the relative activity of monomers in the copolymerization reactions of $\mathrm{N}, \mathrm{N}^{\prime}-(4,4-$ diphenylmethane)bismaleinimide $\left(\mathrm{M}_{1}\right)$ and Styrene $\left(\mathrm{M}_{2}\right)$

\begin{tabular}{|c|c|c|c|c|c|c|c|c|c|c|}
\hline \multicolumn{2}{|c|}{$\begin{array}{l}\text { Initial mixture } \\
\text { of monomers }\end{array}$} & \multirow{2}{*}{$\begin{array}{l}\text { Yield, } \\
\%\end{array}$} & \multicolumn{2}{|c|}{$\begin{array}{c}\text { The amount of monomer in } \\
\text { the copolymer is } \%\end{array}$} & \multirow{2}{*}{$\mathrm{r}_{1}$} & \multirow{2}{*}{$r_{2}$} & \multirow{2}{*}{$r_{1} \cdot r_{2}$} & \multicolumn{3}{|c|}{ Microstructure of copolymers } \\
\hline $\mathrm{M}_{1}$ & $\mathrm{M}_{2}$ & & $\mathrm{~m}_{1}$ & $\mathrm{~m}_{2}$ & & & & $\mathrm{~L}_{\mathrm{M}_{1}}$ & $\mathrm{~L}_{\mathrm{M}_{2}}$ & $\mathrm{R}$ \\
\hline 10 & 90 & 16.0 & 0.06 & 99.4 & \multirow{5}{*}{0.12} & \multirow{5}{*}{12.51} & \multirow{5}{*}{0.10} & 1.002 & 164.8 & 1.204 \\
\hline 25 & 75 & 19.0 & 1.7 & 98.3 & & & & 1.006 & 55.6 & 3.53 \\
\hline 50 & 50 & 15.5 & 5 & 95 & & & & 1.02 & 19.2 & 9.89 \\
\hline 75 & 25 & 16.5 & 13 & 87 & & & & 1.06 & 7.06 & 24.63 \\
\hline 90 & 10 & 12.5 & 28 & 72 & & & & 1.18 & 3.02 & 47.61 \\
\hline
\end{tabular}

$\mathrm{Lm}_{1}$ and $\mathrm{Lm}_{2}$-the ratio of monomer blocks; R-the Harvurd block coefficient.

Table 2. Effect of their composition on the properties of copolymers obtained in the copolymerization reactions of $\mathrm{N}$, N'- (4,4-diphenylmethane)bismaleinimide $\left(\mathrm{M}_{1}\right)$ and styrene $\left(\mathrm{M}_{2}\right)$

\begin{tabular}{|l|c|c|c|c|c|}
\hline № & $\begin{array}{c}\text { The amount of styrene in the monomer } \\
\text { mixture, mass } \%\end{array}$ & $\begin{array}{c}\text { Amount of } \mathrm{m}_{1} \text { in copolymers, } \\
\text { mass \% }\end{array}$ & $\begin{array}{c}\text { Yield, } \\
\%\end{array}$ & $\begin{array}{c}{[\eta]} \\
\mathrm{dl} / \mathrm{g} .\end{array}$ & $\begin{array}{c}\text { Viscosity, } \\
\mathrm{T}^{0} \mathrm{C}\end{array}$ \\
\hline 1 & 0.0 & 0 & 84.0 & 0.78 & 83 \\
\hline 2 & 5.0 & 0.32 & 20.5 & 0.66 & 77 \\
\hline 3 & 10.0 & 1.20 & 15.2 & 0.43 & 72 \\
\hline 4 & 25.0 & 2.5 & 12.00 & 0.30 & 70 \\
\hline 5 & 50.0 & 4.0 & 10.5 & 0.22 & 66 \\
\hline
\end{tabular}

The research of antimiocrobe properties of the copolymer was studied in series by dilution method [10-12]. It was held in the following ratios $(1: 100,1: 200,1: 400,1: 800)$. Newly synthesized copolymer influence to various microorganisms differently and when diluted in 1:100 ratio substance show strong antimicrobial activity against all tested test cultures.

Antimicrobe impact of copolymer was stu- died comparatively with alcohol, rivanol and nitrofungine that are widely used in medicine. The tests are repeated every 15, 30, 45, 60 minutes. The duration of incubation for bacteria is $18-24$ hours at $37^{\circ} \mathrm{C}$.

Tested substance has killed Candida in 1:800 ratio dilution during 10 minute. Examined copolymer can be suggested as antimicrobial substance. 


\section{Conclusions}

1. The regularities of the radical copolymerization reactions of unsaturated cyclic N,N'bisimides of maleic acid with styrene were studied, the composition and structure of the obtained copolymers were also studied on the basis of IR spectra.

2. The dependences of copolymerization reaction rate, composition of the obtained copolymers, composition and molecular weight estimation on the composition of the initial monomer mixture were studied. With increasing the amount of bismaleimide in the initial monomer mixture there is a decrease in the yield of copolymerization reaction and the molecular weight of the obtained copolymers. This fact can be explained by active participation of bismaleimide in chain transfer in radical copolymerization reaction.

3. It has been shown that in the copolymerization reaction of maleic acid bisimide with styrene, styrene has a high activity. As the number of bismaleinimide links in the copolymer of bismaleinimide with St decreases, the rate and degree of polymerization reaction decreases.

The antimicrobial properties of the copolymer were studied in series by dilution method. The obtained copolymer has antimicrobial properties against Candida fungus. The studied compound can be proposed as an antimicrobial agent.

\section{References}

1. Shtil'man M.I. Polimery medikobiologicheskogo naznacheniya. M.: Akademkniga, 2006. 420 s.

2. Yegorova Ye.I. Osnovy tekhnologii polistirol'nykh plastikov. Yegorova Ye.I., Koptenarmusov V.B. SPb.: Khimizdat, 2005. 300 s.
3. Pat. RU 2192433. Funktsionalizirovannyye polimery i sopolimery stirola. Peytil Ebkhimen'yu O. (US), 2002.11.10

4. Sukhinina O.A. Khimicheskaya modifikatsiya polistirola i sopolimerov stirola. Dis... kand. khim. nauk, Moskva, 1999

5. Semenycheva L.L., Artemov A.N., Moykin A.A.. Sintez sopolimerov stirola i yego analogov kompensatsionnym sposobom. Vestnik YUUrGU. Seriya Khimiya. 2016. T. 8. № 2. S. 5-14.

6. AlikhanovaA.I., Rasulzade N.Sh. Polucheniye i issledovaniye sopolimerov tsiklicheskikh bisimidov so stirolom. IV Vseross. Konf. "Khimiya i khimicheskaya tekhnologiya: dostizheniya i perspektivy”, Kuzbasskiy gos. tekhn. Un-tet imeni T.F.Gorbacheva, Rossiya, 2020. C. 671-672.

7. Olixanova A.İ, Salahov M.S., Bağmanov B.T., Mürşüdova L.Ş. Polixlorlu tsiklik dikarbon turşularının bisimidlərinin sintezi, stereokimyası və DilsAlder reaksiyası üzrə polikondensləşməsi. "Funksional monomerlər və polimerlər" mövzusunda hazırlanan toplu, Sumqayit. 2012. № 1. C. 115-125.

8. Rafikov S.R., Pavlova S.A., Tverdokhlebova I.I. Metody opredeleniya molekulyarnykh vesov i polidispersnosti vysokomolekulyarnykh soyedineniy. M.: Izd. AN SSSR., 1963. 334 s.

9. Prech E., Byul'mann F., Affol'ter K. Opredeleniye stroyeniya organ. soyed. M: Mir, 2006.

10. Pozdeyev O.K., Pokrovskiy V.I. Med. Mikrobiologiya. Ucheb. dlya vuzov GEOTAR MED, $2001.768 \mathrm{~s}$.

11. Alikhanova A.İ. Rasulzadeh N.Sh., Zeynalova S.Q., Rasulov N.Sh. Investigation of the antibacterial properties of polychlorinated cyclic bisimides. SSRG İnternational J. Chem. Engineering Research. 2019. V. 6. İssue 1. P. 4-6.

12. Guliyeva S.I., Alikhanova A.İ. Synthesis and study of biologically active additives for antibacterial composition materials. Национальная ассоциация ученых, Хим. науки 50. 2019. С. 56-57.

\section{TSIKLIK DOYMAMIȘ BISMALEIMIDIN STIROLLA BİRGəPOLIMERININ ALINMASI Və XASSəLӘRININ TODQIQQi}

\section{A.İ.Olixanova, R.Ş.Rəsulzadə}

Məqalə doymamış tsiklik imidlərin $\left(\mathrm{M}_{1}\right)$ stirol $\left(\mathrm{M}_{2}\right)$ ilə radikal birgəpolimerləşmə reaksiyalarının tədqiqinin nəticələri və qanunauyğunluqlarının öyrənilməsinə həsr olunmuşdur. Birgəpolimerləşmə reaksiyasının sürəti, alınan birgəpolimerlərin tərkibi və molekul kütləsinin qiymətinin ilkin monomer qarışıgının tərkibindən asılılıgı öyrənilmişdir. İlkin monomer qarışıgının tərkibində bismaleimidin miqdarının artması ilə birgəpolimerləşmə reaksiyasının çıxımının və alınan birgəpolimerlərin molekul kütləsinin azalması müşahidə edilir. Bu faktı radikal birgəpolimerləşmə reaksiyasında bisimid zəncirin ötürülməsi reaksiyasında aktiv iştirak etməsilə izah etmək olar. Alınan birgəpolimerlərin tərkibi bütün hallarda stirol manqaları ilə zəngin olur.

Açar sözlor: doymamış tsiklik imidlər, stirol, birgəpolimer, sopolimer, birgəpolimerləşmə sabitləri, antibakterial və funqal xassalar. 


\section{ПОЛУЧЕНИЕ И ИЗУЧЕНИЕ СВОЙСТВ СОПОЛИМЕРА ЦИКЛИЧЕСКОГО НЕНАСЫЩЕННОГО БИСМАЛЕИМИДА СО СТИРОЛОМ}

\section{А.И.Алиханова, Р.Ш.Расулзаде}

Статья посвящена изучению закономерностей получения реакций радикальной сополимеризации ненасыщенных циклических $\mathrm{N}, \mathrm{N}^{\prime}-$ бисимидов $\left(\mathrm{M}_{1}\right)$ со стиролом $\left(\mathrm{M}_{2}\right)$, изучению зависимости скорости реакции сополимеризации, состава полученных сополимеров, состава и оценки молекулярной массы от состава исходной мономерной смеси. С увеличением количества бисмалеимида в исходной мономерной смеси наблюдается снижение выхода реакции сополимеризации и молекулярной массы полученных сополимеров. Этот факт можно объяснить активным участием бисимида в передаче цепи в реакции радикальной сополимеризации. Состав полученных сополимеров во всех случаях богат стирольными звеньями.

Ключевые слова: ненасыщенные цүиклические бисимиды, стирол, сополимер, константы сополимеризации, антибактериальные и фунгицидные свойства. 